\title{
ARTI PENTING NILAI BAGI MANUSIA DALAM KEHIDUPAN BERMASYARAKAT (Suatu Kajian Dari Filsafat Hukum)
}

\author{
Oleh : \\ M. Syahnan Harahap, SH, M.Hum \\ Kepala Penjamin Mutu Fakultas Hukum - Universitas Suryadarma
}

\begin{abstract}
Abstrak :
Dalam filsafat akseologis (filsafat nilai), nilai adalah suatu keberhargaan (worth) atau kebaikan (goodness). Ini merupakan suatu prestasi yang didapat dalam perjalanan hidup seseorang dan atau kelompok-kelompok yang ada didalam masyarakat. Norma yang ada dalam masyarakat harus dijadikan sebagai tolak ukur untuk berperilaku dan atau bersikap tindak. Predikat nilai baik atau buruk, benar atau salah dan sesuai atau bertentangan dengan hukum yang berlaku dimasyarakat. Nilai yang diperoleh oleh seseorang sangat tergantung kepada penilai pihak lain.
\end{abstract}

\section{PENDAHULUAN}

Dalam sejarah kehidupan manusia selalu terdapat nilai-nilai yang berbeda dan selalu berpasangan. Sebagai contoh nilai baik dan buruk, nilai benar dan salah, nilai etika dan hukum dan nilai objektif dan subjektif.

Pelaksanaan pemberian nilai itu sering menjadi bahan perbincangan, pertikaian dan menjadi rebutan antara orang yang satu dengan orang lain bahkan bisa bertarung nyawa untuk mendapatkannya.

Keserakahan dan ambiguitas manusia dalam pergaulan kosmopolitan, menyebabkan terjadinya perbuatan melanggar hukum. Apalagi dalam diri manusia itu selain memiliki sifat baik juga memiliki sifat jahat. Sebagai contoh klasik adalah Socrates yang hidup pada tahun 399 SM. Dia dituduh merusak jiwa dan pemikiran kaum muda Athena (Louis O Kattsoff, 2008: 233). Socrates sebenernya dihimbau oleh teman-temannya untuk melarikan diri. Teman-temannya siap membantu secara material dan moril dalam pelarian diri itu.

Namun Socrates bertanya dan mengajak diskusi teman-temannya itu, apakah dengan melarikan diri itu akan layak bagi dirinya dan apakah akan mendatangkan nilai baik atau buruk, termasuk apakah akan mendatangkan kebahagiaan. Pada akhirnya Socrates setelah menilai alasanalasan itu dan dia tidak melarikan diri, 
sehingga dia di penjara dan disuruh meminum racun

Contoh lainnya adalah Abraham Samad, Bambang Widjoyanto, dan Novel Baswedan yang perkaranya jelas-jelas sudah siap dilimpahkan kepengadilan, diambil alih oleh jaksa agung akan dilakukan upaya penghentian penuntutan perkara (Deponering) (Sindo, 2016: 4). Lalu timbul pertanyaan, apakah perbuatan ini mendatangkan nilai baik dan atau buruk terhadap kehidupan masyarakat termasuk penegakan hukum di Indonesia.

Oleh karena itu perlu ada perencanaan, perenungan dan pemahaman yang mendalam sebelum mengambil suatu tindakan atau keputusan (action).

\section{PERMASALAHAN}

Dari berbagai permasalahan diatas, maka permasalahan dapat di identifikasi sebagai berikut:

1. Apakah arti penting nilai dalam kehidupan masyarakat?

2. Bagaimanakah cara untuk mengukur suatu nilai, sehingga bermanfaat bagi kehidupan masyarakat?

\section{PEMBAHASAN}

\section{Arti penting nilai dalam kehidupan bermasyarakat}

Sebelum sampai kepada arti penting nilai dalam kehidupan bermasyarakat terlebih dahulu timbul pertanyaan, apakah pengertian nilai itu? samakah pengertian nilai dan menilai? dan apakah macam-macam nilai itu?

\section{a. Pengertian Nilai}

Nilai (value) dalam filsafat aksiologis (filsafat nilai) adalah suatu keberhargaan (worth) atau kebaikan (goodness).

Sedangkan menilai berarti menimbang diteruskan dengan suatu kegiatan manusia untuk menghubungkan sesuatu dengan sesuatu lainnya (Darji Darmodiharjo dan Sidharta, 1995: 234).

Oleh karena itu di dalam melakukan sesuatu penilaian sebelum mengambil suatu tindakan atau keputusan memerlukan perenungan dan pemahaman yang mendalam. Tidak didasarkan prihal suka atau tidak suka, termasuk tergesa-gesa atau tanpa pikir panjang. Sebab suatu keputusan dikatakan baik apabila mendatangkan kebaikan dan bermanfaat bagi kehidupan masyarakat.

Perlu disadari bahwa dalam melakukan suatu penilaian tidak boleh terlepas dari unsur yang ada pada diri manusia yaitu unsur jasmania, cipta, rasa dan karsa serta kepercayaan. Nilai juga dapat diartikan sebagai sifat atau kualitas dan selalu dijadikan landasan, alasan atau motivasi dalam bersikap dan bertingkah laku baik yang didasarkan kepada keadaan utuh (objektif).

b. Macam-macam nilai menurut pendapat para ahli antara lain adalah: 


\section{1) Louis $O$ Kattsoff}

Membedakan nilai dalam dua macam, yaitu nilai intrinsik dan nilai instrumental. Nilai intrinsik adalah nilai yang sejak semula sudah bernilai, sedangkan nilai instrumental adalah nilai dari segala sesuatu karena dapat dipakai sebagai sarana untuk mencapai tujuan. Sebagai contoh pisau akan bernilai apabila dapat memotong dan mengiris sesuatu dengan baik.

\section{2) Max Scheler}

Mengelompokkan nilai atas 4 macam yaitu nilai kenikmatan (rasa enak, nikmat dan senang), nilai kehidupan (kesehatan, kesegaran jasmaniah), nilai kejiwaan (kebenaran dan keindahan) dan nilai kerohanian yaitu kesucian.

\section{3) Walter G. Everet}

Menggolongkan nilai lebih rinci lagi yaitu nilai ekonomis, nilai jasmaniah, nilai hiburan, nilai sosial, nilai watak, nilai estetika, nilai intelektual dan nilai keagamaan.

Menindak lanjuti hal tersebut di atas ternyata nilai itu tidak hanya dalam benda berwujud akan tetapi juga dalam benda yang tidak berwujud. Benda berwujud adalah setiap benda yang dapat dilihat, di raba dan atau dapat ditangkap oleh panca indra manusia. Sebagai contoh kerbau punya nilai ekonomis dan halal untuk diperdagangkan dan dapat dijadikan makanan untuk manusia.
Sedangkan benda tidak berwujud adalah setiap benda yang tidak dapat dilihat, diraba atau ditangkap dengan panca indra manusia sebagai contoh jasa guru, dokter, dan tukang jahit, mempunyai nilai ekonomis artinya nilai itu bisa diperjual belikan karena bermanfaat bagi kehidupan manusia.

Manusia tidak dapat membantah atau bahkan tak terbantahkan bahwa hidup itu bermakna gerak. Kehidupan itu selalu terdapat dalam ruang, waktu dan keadaan. Untuk itu agar manusia dapat hidup dengan baik harus dapat menyesuaikan diri dengan lingkungan dan hal-hal yang berlaku dalam kehidupan masyarakat yang bersangkutan.

Dalam kehidupan masyarakat, manusia itu adalah sebagai pelaku dan akan terlihat nilai dalam suatu tindakan, artinya apakah punya nilai manfaat bagi anggota masyarakat atau tidak terdapat kepuasaan atau tidak, itu akan terjadi apabila tindakan itu sesuai atau bertentangan dengan keinginan masyarakat.

Patut disadari bahwa manusia itu punya sifat ambiguitas, keserakahan, jahat, penakut dan memiliki kebebasan absolut. Dunia manusia dikelola prinsip homo homonilupus, manusia saling menjadi serigala bagi yang lainnya dan belum omnium contra omnes, peperangan semua melawan semua (I. Bambang Sugiarto, 2008: 301).

Dalam kehidupan manusia dapat kita ketahui yang terjadi adalah 
saling membunuh dan saling memakan terkesan kejam dan sadis. Tetapi itu adalah fakta, manusia makan daging kerbau, tumbuhtumbuhan dan pada akhir kehidupan manusia suatu waktu sebelum menjadi tanah akan dimakan cacing, ulat dan belatung.

Thomas Hobes mengatakan bahwa pada awalnya kehidupan manusia itu adalah liar dan buas. Oleh karena itu manusia yang lemah bersatu dan menitipkan dirinya kepada orang kuat untuk diurus, dijaga dan diatur serta dibuat kedalam suatu kontrak sosial yang pada akhirnya muncul negara sebagai ikatan persatuan manusia untuk mencapai tujuan bersama.

Oleh karena itu manusia dalam kehidupannya harus dapat memanusiakan manusia agar manusia tersebut dapat memiliki nilai atau arti baik bagi manusia lainnya. Harus menjadi homo homoni soisus. Itupun tergantung persoalannya kepada manusia sebagai inti dalam pejuangan hidupnya dimuka bumi. Jadi kehidupan itu serba misteri dan penuh teka-teki tidak selalu konkrit akan tetapi bisa juga abstrak.

Jadi manusia adalah makhluk yang dengan perbuatannya berhasrat untuk mencapai dan atau merealisasikan nilai-nilai sama dengan hasil (Muhammad Erwin, 2011: 29).

Aritoteles mengatakan semua perbuatan manusia senantiasa ada kehendak untuk melakukan perbuatan baik, ia merupakan sesuatu yang dikejar dalam kehidupan manusia.

Saya teringat puitik Rene Des Cartes, Coqit Ergo Sum, akan berpikir karena aku ada. Memang fakta manusia berfikir ini merupakan peralatan atau senjata utama untuk menjamah filsafat ilmu.

Dalam nilai moral harus dikedepankan dalam berfikir, sejarah filsafat terbukti ketika kaum sophist Yunani hidup dalam kegemerlapan dan dalam keserakahan mencari keuntungan pribadi maupun untuk kelompoknya. Socrates dengan tegar melakukan perlawanan, mengkritik kaum sophistis dan hidupnya tragis. Dimana pada akhirnya ia dihukum mati dengan disuruh minum racun oleh penguasa yang sedang berkuasa.

Hal ini dilakukan untuk mempertahankan kebenaran. Juga hal yang tidak kalah pentingnya agar kehidupan manusia menjadi lebih bernilai atau bermakna bagi kehidupan manusia, terutama dalam menyampaikan perasaan atau ide dalam sesamanya perlu memperhatikan bahasa. Bahasa yang komunikatif, agar isi pesan dari komunikator sampai kepada komunikan dan mendapatkan respon dari komunikan tentang nilai baik dan atau buruk.

Bambang Sugiarto mengatakan bahwa bahasa bukan sekedar ungkapan pengalaman, artinya bahasa adalah pengalaman yang menyadari diri sendiri sebagai 
pengalaman tentang ini dan itu. Manakala kita menemukan cara yang halus untuk mempertahankan emosi kita, sebenarnya kehidupan emosional itu sudah menjadi lebih halus bukan sekedar cara kita memaparkan saja.

Bila benar yang dikatakan Heidinger bahwa bahasa adalah rumah tempat tinggal kita. Kalau lebih benar lagi bila kita mengatakan bahwa bahasa adalah rumah bagi pengalamanpengalaman yang bermakna. Pengalamn tidak akan bermakna apabila tidak menemukan rumah dalam bahasa. Sebaliknya tanpa pengalaman nyata bahasa adalah ibarat kerang yang kosong tanpa kehidupan (I. Bambang Sugiarto, 1996: 96).

Dengan demikian bahasa adalah kunci sukses dari kehidupan. Dalam konteks ilmu komunikasi bahasa adalah peralatan rohaniah manusia yang harus diekspresikan dalam peralatan jasmaniah agar mendatangkan nilai manfaat bagi kehidupannya. Moral dan agama adalah pedoman dalam berbahasa. Selain itu bahasa hukum juga harus benar jangan homophon artinya multi tafsir. Agar keadilan dan kepastian hukum dapat dirasakan sebagai nilai atau catatan dalam pergaulan hidup seseorang atau dalam suatu masyarakat dalam rimba raya yang penuh misteri ini.

\section{c. Arti Penting Nilai dalam kehidupan bermasyarakat}

Pada suatu hari Socrates menelusuri jalan ke kota Athena, mengucapkan suatu perkataan "kenalilah diri sendiri ". Dalam waktu lain Alexander Pope mengatakan penyelidikan mengenai umat manusia dalam arti yang sebenarnya hendaklah ditujukan kepada manusia itu sendiri.

Dalam masyarakat kita terdapat pepatah "karena nilai setitik rusak air susu sebelanga". Artinya adalah dengan suatu perbuatan yang buruk menyebabkan perbuatan baik yang selama ini dilakukan akan rusak. Tidak ada lagi harganya dimata masyarakat.

Dari berbagai pernyataan diatas, apabila kita hendak melakukan suatu tindakan atau keputusan haruslah beranjak dari kata hati nurani. Karena hati nurani itu tidak pernah berbohong, selalu jujur dan berada diatas jalan yang lurus. Memiliki sifat otonom artinya apa yang baik dalam hati nurani itu, itulah yang harus dijadikan ukuran untuk melakukan suatu tindakan

Selain itu adalah perbuatan baik yang berserahkan dalam kehidupan masyarakat (heteronom) artinya apa yang baik yang terdapat dalam kehidupan masyarakat itulah yang dijadikan sebagai ukuran untuk melakukan suatu tindakan.

Dengan demikian dapat diketahui bahwa arti penting nilai kehidupan masyarakat adalah sebagai sarana untuk dapat membedakan perbuatan baik atau buruk, benar dan salah,objektif dan subjekif serta sesuai dengan kehendak masyarakat. Sifat heteronom itu 
perlu dilakukan dalam kerangka hubungan sosial.

Selanjutnya untuk memperkuat pikiran kita, dalam masyarakat romawi hukum itu dibangun berdasarkan etika yang kuat, yaitu Honeste Vivere artinya berlakulah jujur, Neminem Laeder artinya jangan bertindak merugikan orang lain dan Suum Cuicue Tribuere artinya berikanlah apa yang menjadi hak orang lain (W. Friedmann, 1990: 12).

\section{Cara mengukur nilai agar bermanfaat bagi kehidupan masyarakat}

Menurut Thomas Aquinas, seorang rohaniawan Gereja Katolik (12251275) mengatakan bahwa ukuran untuk menentukan kebenaran adalah akal budi (Theo Huijbers OSC, 1982: 39). Dengan demikian apa yang tampak dalam tingkah laku seseorang itulah yang menjadi ukuran. Ukuran ini tidak objektif akan tetapi subjektif.

Sedangkan Soegono Dirdjosisworo, mengatakan bahwa tolak ukur kebenaran alam didasarkan kepada sendi ilmu pengetahuan dan secara khas dalam filsafat epistimologi dan logika.

Apabila dikaji berdasarkan ilmu hukum sosiologis, bahwa penilaian hukum dalam tindak tanduk manusia dijadikan sebagai ukuran. Jadi hukum dilihat dari tindak tanduk manusia (Rudi T. Erwin, 1983: 53).

George E. More secara cemerlang bahwa ukuran kebenaran itu adalah realitas, serasi, dan rasional serta logis. Berbeda dengan Soekrates kebenaran objektif adalah merupakan pedoman- pedoman yang berlaku tetap. Kekuasaan akal budi adalah alat untuk meyakini kebenaran.

Dengan demikian berdasarkan hal-hal tersebut diatas dapat diketahui bahwa ukuran tentang nilai dalam kehidupan di masyarakat adalah norma atau kaidah yang berlaku universal, nasional dan lokal. Kaidah-kaidah tersebut adalah:

a. Kebiasaan-kebiasaan yang berlaku di masyarakat,

b. Kesusilaan,

c. Kesopanan,

d. Hukum,

e. Akal budi manusia,

f. Kebijaksanaan,

g. Keputusan pejabat, dan

h. Kaidah ketuhanan.

Berdasarkan hal tersebut diatas dapat diketahui bahwa tuntunan praktis untuk mendapatkan kebaikan bersama dan dapat dijadikan sebagai sarana untuk memecahkan problemaproblema hukum. Selain itu nilai akan dapat meningkatkan harkat dan martabat manusia. Jadi penting untuk menerapkan patokan-patokan nilai yang dapat diterima oleh bermacammacam manusia (W. Friedmann, 1990: 131)

\section{PENUTUP}

\section{Kesimpulan}

a. Nilai adalah kualitas empiris yang akan menentukan suatu tindakan atau keputusan. Nilai akan menentukan prestasi dan kualitas martabat seseorang. Semakin baik penilaian terhadap seseorang atau suatu kelompok masyarakat, maka 
akan semakin berkualitas atau semakin berharga seseorang atau kelompok - kelompok yang ada dalam masyarakat. Kebaikan itu harus rasional artinya dapat diterima segenap anggota masyarakat.

b. Cara mengukur nilai harus berdasarkan nilai-nilai yang hidup dan berkembang di masyarakat, seperti kebiasaan - kebiasaan masyarakat, kepercayaankepercayaan, kekuatan akal budi, hukum dan etika, kebijaksanaan atau keputusan pejabat. Ini harus dijadikan sebagai patokan atau ukuran untuk bertingkah laku yang dapat bermanfaat bagi kehidupan masyarakat. Hukum akan sampai kepada tujuan apabila dapat mendatangkan kemakmuran dan kebahagian bersama.

\section{Saran}

Norma harus dijadikan sebagai patokan untuk menilai sesuatu. Dan harus didasarkan kepada nilai-nilai yang hidup dan berkembang dimasyarakat seperti nilai ketuhanan, kebiasaan, kesusilaan dan hukum.

\section{DAFTAR PUSTAKA}

Darji Darmodiharjo dan Sidharta, PokokPokok Filsafat Hukum, Penerbit Gramedia, 1995.

I.Bambang Sugiarto, Postmodernisme, Penerbit Kanisius, Yogyakarta, 1996.

I.Bambang Sugiarto, Humanisme dan Humaniora, Penerbit Jalasutra, Yogyakarta, 2008.
Louis O Kattsoff, Pengantar Filsafat, Penerbit Tiara Wacana, Yogyakarta, 2008.

Muhammad Erwin, Filsafat Hukum, Penerbit Raja Grafindo, Jakarta, 2011.

Rudi T. Erwin, Tanya Jawab Filsafat Hukum, Penerbit Aksara Baru, Jakarta, 1983.

Theo Huijbers OSC, Filsafat Hukum dalam Lintasan Sejarah, Penerbit Yayasan Kanisius, Yogyakarta, 1982.

W. Friedmann, Teori dan Filsafat Hukum, Penerbit Raja Wali, Jakarta, 1990.

Sindo, Jaksa Agung Degradasikan Peran Polri, Jakarta, 2016. 